\title{
話速変換に伴う周波数変化修正の一方法
}

\author{
川澄正史 (正会員)*, 大西孝史 (非会員)**, 志村隆史 (非会員)**, 平松啓二(正会員)***
}

\section{A Correcting Method for Frequency Changes in Speech Speed Converting Process}

\author{
Masashi Kawasumi*, Takafumi Ohnishi**, Takashi Shimura** and Keiji Hiramatsu***
}

\begin{abstract}
In order to listen to recorded speeches quickly or slowly (compared to normal speed), it is necessary to change the playback speed of player. Since the speech waveforms are compressed or expanded in time axis according to the playback speed, this operation obviously causes damage to tone quality of voice, individuality of speaker, and understanding of the recorded speech. To fix the quality of the affected speech, there are two approaches, namely, cutting or pasting of these damaged waveforms in time domain and correcting the shifted tone in frequency domain. The latter approach has advantages in holding frequency features of the speech through the process. We have been investigating a method of the approach in which the instantaneous frequency of signal is modifiable to any value. In this paper, this method is introduced and simulation results are discussed. In the results, both individuality of speaker and understanding of the recorded speech are almost fixed.
\end{abstract}

\section{Key Words}

Speech signal processing, Player, Play back speed, Listening aid, Elderly

\section{1.はじめに}

高鸰者においては，早口の会話やメディアからの音声， 放送等を闑き取りにくいと感じる場合が少なくない。この ような音声注，録音されていれば標準再生速度よりも低速 に再生することで聞き取りやすくなるといえる．また，力 セットテープや VTR などに録音された音声を低速に再生

1998 年 10 月 29 日受付・受理

* 東京電機大学工学部情報通信工学科

** 元東京電機大学大学院工学研究科修士課程

$* * *$ 東京電機大学名兴教授, 東京電機大学総合研究所

東京都千代田区神田錦町2-2(广 101-8457)

* Department of Information and Communication Engineering, College of Engineering, Tokyo Denki University

* * Graduate School of Tokyo Denki University

$* * *$ Emeritus Professor, and Adviser of Research Institute for Technology, Tokyo Denki University 2- 2 Kanda-nishiki-cho, Chiyoda-ku, Tokyo 101 $-8457$
すると議事録の作成や外国語会話など内容の十分な確認に も役立ち, 高齢者への伝達手段としても有効である ${ }^{1)}$. 逆 に，高速に再生すれば録音内容の概要を短い時間で理解す ることができる．しかし，再生速度を変えることにより音 声波形は時間軸上で伸び縮みし，高速再生はキンキン声 に，低速再生は低くこもった声に変わり，個人性が失わ れ，話者の特定も困難となる，そのため再生速度を高速あ るいは低速に変更すると同時に，声質を録音時のものに戻 す修正処理が必要となる ${ }^{2,3)}$. このような話速変換の処理は 時間軸圧縮伸張処理と呼ばれる(以後, 圧伸処理という).

圧伸処理には，時間軸上で処理する方法と周波数軸上で 処理する方法とがある. 時間軸上での処理方法として，音 声波形を有声，無声，無音の各区間に分類し，継足しある いは間引きをおこなう方法などが考えられる ${ }^{4}$. しかし， この方法は伸び縮みする前の元の音声波形の継ぎ貼りだか ら，圧伸処理後の音声における母音・子音・無音区間の時 間比率は録音前の比率とは異なってしまう。

本論文では，再生速度比に応じた圧伸処理を周波数軸上 で実現する一方法について，実時間処理可能なアルゴリズ ムを作成し，シミュレーションをおこなったので報告する。 
本方法では，音声がすでに高速にあるいは低速に録音さ れている場合でも，元の声質に戻すことができる．音声波 形の継足し・間引きではないので録音時の母音・子音・無 音区間の時間比率を保ち，声質修正をおこなえる．すなわ ち時間情報を失うことなく圧伸率を自由に変えることがで きる.以下のシミュレーションはワークステーションでお こなっている. 実時間処理のためのハード化を考慮し， 1 ステップずつ処理可能なプログラムで記述されている.

\section{2. 压伸処理方法}

\section{1 本方法の特徵}

従来の話速変換では，波形に重点をおいた処理が主体で あるために情報の欠落が目立ち，声質に期待できなかっ

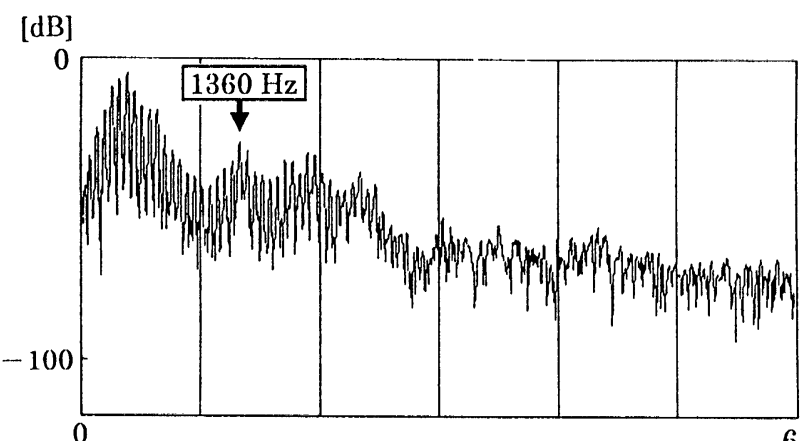

(a) $\alpha=0.5$ (half speed)

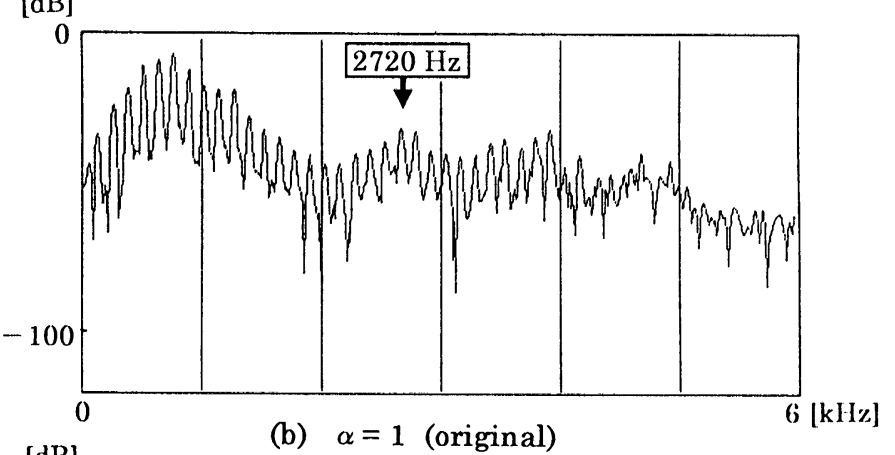

[dB]

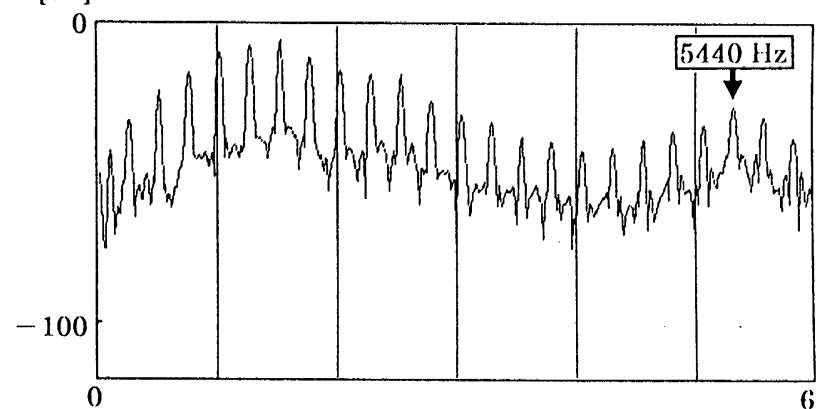

(c) $\alpha=2$ (double speed) $6[\mathrm{kII} \mid$

Fig.1 Frequency spectra obtained from recorded same vowel /a/ playbacked (a) slowly, (b) normally and (c) quickly (Ratio $\alpha=$ playback $\div$ recording speed) 2nd formants(marked) are shifted due to playback speed.
た. FFTと符号化方式による処理は整合等の手順が多く, 自然性に問題があり，多くの補足処理 ${ }^{5}$ が必要であった. VOCODER 方式は音声パラメータに対して高い加工の自 由度を有していることから高品質が期待される ${ }^{6)}$ 。信号抽 出能力が劣化する高齢者を対象にする場合には高品質化が 望まれる". 本方式では VOCODER 方式を取り入れてい

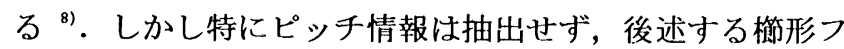
イルタを採用して基本周波数の高調波を分離しているため 自然性が期待できる. 解析信号を用いて得られる瞬時周波 数の值を再生速度に忘じた值に修正寸るという，原理に忠 実な方式である。

\section{2 圧伸処理の原理}

圧伸係数 $\alpha$ を次式で定義する.

$$
\alpha=\frac{\text { 変更再生速度 }}{\text { 標淮再生速度 }}
$$

$\alpha$ を 0.5，1，2 倍として再生したときの音声(母音/a/)の周 波数スペクトルを Fig.1 に示寸. 圧伸係数 0.5 は低速再生 された音声，1 はオリジナル音声，2 は高速再生された音 声を意味する.フォルマント周波数はじめ音声の特徽が周 波数軸上で移動してしまうことがわかる.

母音のような周期性信号は，基本周波数とその高次の成 分より構成される.すなわち母音は次式で近似できる。

$$
\sum_{i=0}^{n} \mathrm{~A}_{i}(t) \cos \left(2 \pi i f_{0} t+\phi_{i}\right)
$$

ここで, $\mathrm{n}$ は高次次数， $\mathrm{f}_{0}$ は基本周波数であり, $\mathrm{Ai}(\mathrm{t})$ および $\phi_{\mathrm{i}}$ は $\mathrm{i}$ 次の振幅および位相をめらわす。 圧伸係数を任意に選び再生速度を変更した場合の母音は次 式であらわされる.

$$
\sum_{i=0}^{n} \mathrm{~A}_{i}(t / \alpha) \cos \left(2 \pi \alpha i f_{0} t+\phi_{i}\right)
$$

位相の変化は，人間には感知されない。よって(3)式の位 相項 $\phi_{\mathrm{i}}$ は無視して考える. (3)式によれば任意の $\alpha$ に応じ た母音の圧伸処理は，次の原理で実現できる。「 $\alpha$ 倍の速 度で再生した音声の基本周波数の振幅と，基本周波数の高 調波成分の振幅とを保存したまま周波数だけを $1 / \alpha$ 倍寸る ことで実現できる」

子音には，母音と違い調波構造が存在しない，子音の構 造は, 特定の帯域に集中するスペクトル分布構造で特微づ けられる．つまりスペクトルのエンベロープ情報を修正す ればよい. 再生速度を変更した場合には $\alpha$ 倍だけそのスペ クトルがシフトされる.よって子音の圧伸処理は次の原理 で実現できる。「母音と同様に，振幅を保存したまま周波 数を $1 / \alpha$ 倍寸れば実現できる」 


\section{3 解析信号と瞬時周波数の定義}

圧伸処理のために解析信号を用いる. 解析信号より得ら れる瞬時周波数信号を $1 / \alpha$ 倍に修正する. 解析信号 $\mathrm{Sa}(\mathrm{t})$ は実信号 $\mathrm{S}(\mathrm{t})$ ，その位相を $\pi / 2$ シフトさせた信号 $\hat{\mathrm{S}}(t) \quad$ と を用いて次式のように定義する． $\hat{\mathrm{S}}(t)$ は $\mathrm{S}(\mathrm{t})$ をヒルベ ルト変換して求める.

$$
\begin{aligned}
\mathrm{S} a(t) & =\mathrm{S}(t)+j \hat{\mathrm{S}}(t) \\
& =a(t) \exp (j \phi(t))
\end{aligned}
$$

(4) 式中の包絡線信号 $a(t)$ と位相 $\phi(t)$ は次式となる.

$$
\begin{aligned}
& a(t)=\sqrt{\mathrm{S}^{2}(t)+\hat{\mathrm{S}}^{2}(t)} \\
& \phi(t)=\tan ^{-1} \frac{\hat{\mathrm{S}}(t)}{\mathrm{S}(t)}
\end{aligned}
$$

瞬時周波数信号 $\mathrm{fi}(\mathrm{t})$ は次式となる.

$$
\begin{aligned}
f_{i}(t) & =\frac{1}{2 \pi} \frac{d \phi(t)}{d t} \\
& =\frac{1}{2 \pi} \frac{\mathrm{S}(t) d \hat{\mathrm{S}}(t) / d t-\hat{\mathrm{S}}(t) d \mathrm{~S}(t) / d t}{\mathrm{~S}^{2}(t)+\hat{\mathrm{S}}^{2}(t)}
\end{aligned}
$$

以上のように，ゆっくりと変化する音声信号 $\mathrm{S}(\mathrm{t})$ の包絡線 と，瞬時周波数信号とを分離して処理する.

\section{4 圧伸処理の流れ}

母音の基本周波数は低くても $80 \mathrm{~Hz}$ 程度である.この場 合, 母音の周波数帯域全体を帯域幅 $80 \mathrm{~Hz}$ の隣接する帯域 フィルタ群で分割すれば，基本周波数 $80 \mathrm{~Hz}$ の高調波は各 帯域フィルタ(以後, BPF)の出力から正弦波状信号として それぞれ抽出できる.

Fig.2 に压伸処理の流れを示寸. 各帯域内(すなわち各チ ヤネル内)では全く同じ処理をすればよい. 再生速度が $\alpha$ 倍に変更された場合には，帯域幅 $80 \times \alpha[\mathrm{Hz}]$ の各 $\mathrm{BPF} に$ より各高調波を同様に抽出できる．次に帯域通過信号の包 絡線信号と瞬時周波数信号を計算して求める．両者の值は 時間的に変化する直流值となる. 求めた瞬時周波数信号を $1 / \alpha$ 倍し, この瞬時周波数信号で FM 变調する. 1/ $\alpha$ 倍さ れた瞬時周波数に対応した周波数の一定振幅の波形が得ら れる.これに包絡線信号を乗じ，振幅情報を与える．最終 段階で各チャネルの出力信号すべてを加えれば，各高調波 成分の合成として圧伸処理された音声が得られる.

子音についても母音と同様に $80 \mathrm{~Hz}$ ごとに帯域分割して 圧伸処理をおこなう。

\section{3. シミュレーション}

\section{1 圧伸処理の実現方法}

Fig.2 のブロックを実現するプログラムを作成し，シミ ュレーションをおこなった.

圧伸処理前の音声の帯域幅は, $5 \mathrm{kHz}$ に設定した. 対応 できる再生速度は, 0.5 倍速から 2.0 倍速までの任意の速
度とし，何倍速であるかの值は，再生装置のメカニズムよ り直接に得られるようにする．2.0 倍速のときは, 約 $10 \mathrm{kHz}$ までが処理の対象帯域となる。このためカットオ フ周波数 $10 \mathrm{kHz}$ の折り返し歪除去フィルタを使用する. 僄移域に执いて急峻な减衰特性を得るため, IIR 型 12 次 連立チェビシェフ型フィルタを用いる． $12 \mathrm{kHz}$ において - 40dB の减衰量が得られるので，サンプリング周波数は 標本化定理により $24 \mathrm{kHz}$ を選択した. サンプリング間隔 Tは $41.6 \mu$ sである.

BPF は母音における基本周波数の各高調波成分の抽出 に用いる. BPF の通過帯域幅は音声の基本周波数よりも 狭い必要がある. BPF は遷移域の減衰特性が急峻で, 阻 止域の減衰量は大きくなければならない。ここでは少ない 次数でこの特性が得られるチェビシェフ型 IIR フィルタを 用い，次数を 12 次とする. 帯域幅 $80 \alpha[\mathrm{Hz}]$ の BPF を用 いて $80 \alpha \sim 4880 \alpha[\mathrm{Hz}]$ の 60 チャネルに音声を分割す る. ヒルベルト変換は 90 度位相分割法により実現した. すなわち位相差分波器を用いて, $80 \alpha[\mathrm{Hz}]$ の帯域幅にお いて互いに 90 度の位相差を持つ 2 つの信号を得る.この フィルタの形式は 6 次の IIR 型である.

(7)式中の微分計算にはラグランジェの補間多項式を使

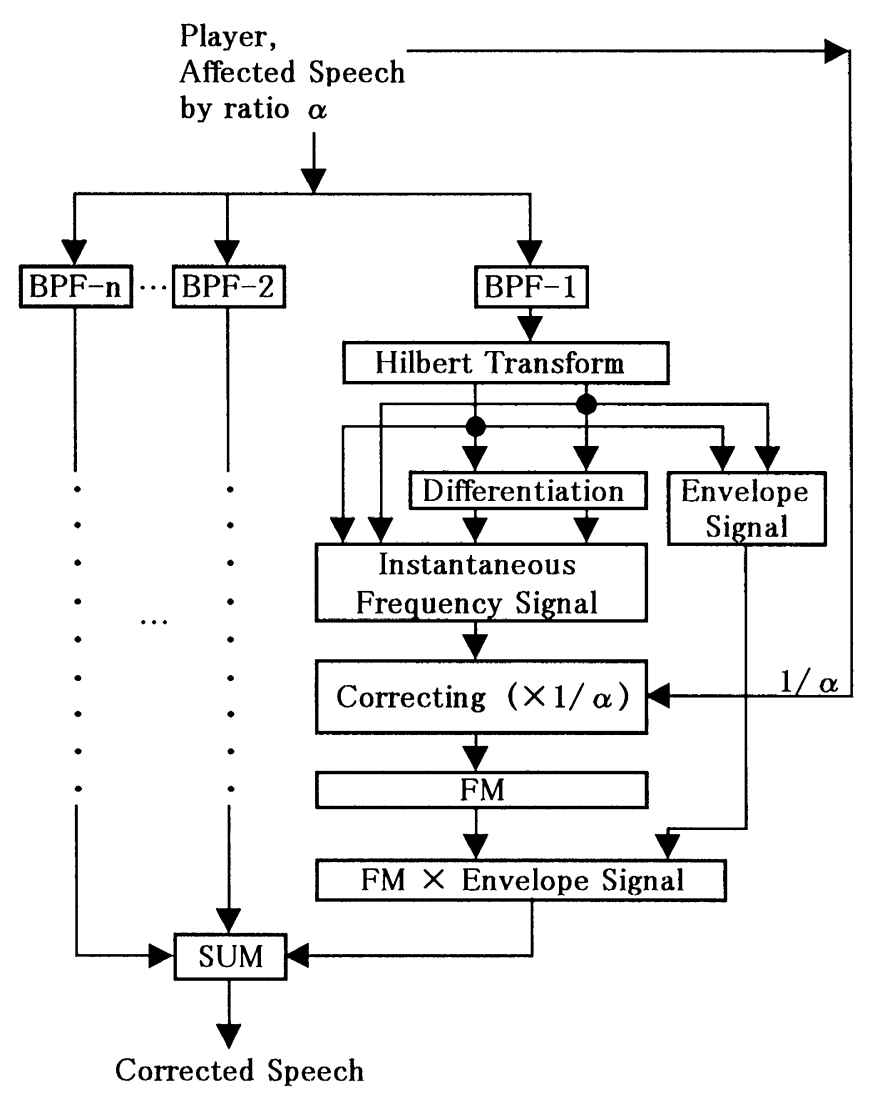

Fig.2 Correcting procedure of affected speech Ratio $\alpha$ should be given by speed controllable player. 
った逐次数值微分法を用いた. すなわち微分值を求めたい 点と隣接するいくつかの点との差分商を基に，ラグランジ エの補間多項式を用いて差分商の近似多項式をたて, 微分 值を計算する．ここでは 6 つの隣接するデータ点を用い る. 近似多項式はたたみ込みの式へと簡単化でき，この場 合は 6 次の FIR 型フィルタにより実現できる.

$\mathrm{FM}$ 変調の一般式は搬送周波数を $\mathrm{fc}_{\mathrm{c}}(\mathrm{t})$, 変調信号を $\mathrm{f}(\mathrm{t})$ として次式であらわせる.

$$
\left[f_{\mathrm{C}}(t)\right]_{\mathrm{FM}}=\mathrm{A}_{\mathrm{C}} \cos \left[2 \pi f_{\mathrm{C}}(t)+k_{\mathrm{FM}} \int f(t) d t\right]
$$

圧伸処理中の FM 変調は瞬時周波数信号の正弦波状波形を 発振させるものである. したがって搬送周波数は不必要と なり, 変調信号 $\mathrm{f}(\mathrm{t})$ は瞬時周波数值 $\mathrm{fi}(\mathrm{t})$ となる. 係数 $\mathrm{kFM}$ はここでは瞬時周波数修正の係数として使用する. 求まっ た瞬時周波数は $\alpha$ 倍だけずれている。したがって， $\mathrm{k}_{F M}$ を $1 / \alpha$ とすることで瞬時周波数を修正できる．また，包絡線 との積により振幅制御をおこなうので $\mathrm{Ac}=1$ とする. これ より本方式で用いる FM 変調の式は次式となる.

$$
\left[f_{\mathrm{C}}(n \mathrm{~T})\right]_{\mathrm{FM}}=\cos \left[2 \pi \frac{1}{\alpha} \int f_{i}(t) d t\right]
$$

この式の積分部を台形則を用いて積分し, 差分形であらわ すと, 次式となる. $\cos$ の計算は正弦波関数を用いずに $\cos x$ を 7 項までマクローリン展開して計算する.

$$
\left[f_{\mathrm{C}}(t)\right]_{\mathrm{FM}}=\cos \left[2 \pi \mathrm{T} \sum_{k=0}^{n} \frac{f_{i}(k \mathrm{~T})+f_{i}(k \mathrm{~T}-\mathrm{T})}{2 \alpha}\right]
$$

\section{2 シミュレーション 1}

成人男声の「東京電機大学」を対象音声とする. サンプ リング周波数を $24 \mathrm{kHz}$ ，圧伸処理後の帯域を 80 $4880 \mathrm{~Hz}$ ，圧伸係数 $\alpha$ を 0.625 (低速再生) および 1.875 （高速再生）として圧伸処理をおこなう.

はじめに, 圧伸処理各過程における単チャネル内の各波 形例を示す. Fig.3 は第 5 チャネル(帯域 $400 \alpha \sim 480 \alpha$ [Hz], $\alpha=0.625$, つまり带域 $250 \sim 300 \mathrm{~Hz}$ )内の信号の例 である. 各波形は，(a)速度を変更して再生された音声の一 部, (b)第 5-BPF 通過後, (c) ヒルベルト変換後の $\mathrm{S}(\mathrm{t})$, (d) ヒルベルト変換後の $\hat{\mathrm{S}}(t) \quad,(\mathrm{e})$ 包絡線信号, (f) 瞬時周波数 信号, (g) $1 / \alpha$ 倍した瞬時周波数信号, (h)FM 変調波, (i)包 絡線信号を乘じて振幅制御した波形，である。振幅制御後 の波形(i)が第 5 チャネルの最終出力波形である.この出力 波形がチャネルごとに同時に得られ，すべて加え合わせた のが，圧伸処理後の音声波形となる。

次に，音声波形を観察する. 音声の一部について Fig.4 に, (a)標準速度での音声波形，(b)高速再生した音声波形 $(\alpha=1.875)$, (c)圧伸処理後の音声波形をそれぞれ示す.

聴覚上に大きな影響を与えるピッチ周期が(a)の間隔に修 正されていることが確認できる. $\alpha=0.625$ の低速再生時 の各波形も，同様の修正がなされていることを確認した.

Fig.5 には, 処理前と処理後における音声全長の波形と スペクトログラムとを示す. スペクトログラムからはフォルマ ント位置や調波構造が復元されていることが確認できる.

次に，圧伸処理結果の音声を試聴した。個人性が保存さ

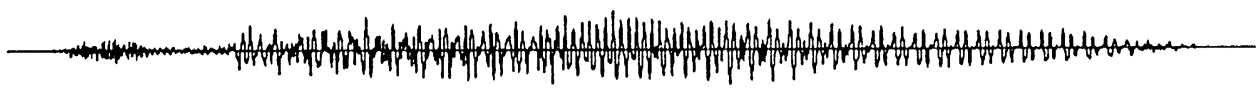

(a) Affected speech signal

(b) Band passed component from \#5 BPF

(c) S(t), output of Hilbert Transformer

(d) $\hat{S}(t)$, output of Hilbert Transformer

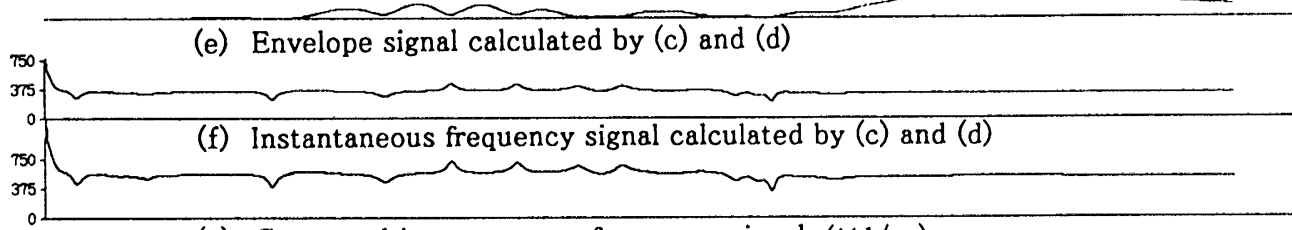

(g) Corrected instantaneous frequency signal $(\times 1 / \alpha)$

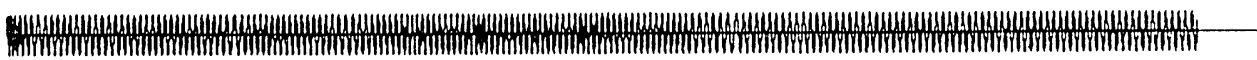

(h) FM signal produced by (g)

(i) (e) $\times(h)$, final output of $\# 5$ channel

Fig.3 An example $(\alpha=0.625)$ of waveforms observed in $\$ 5$ channel $(400 \alpha \mathrm{Hz} \sim 480 \alpha \mathrm{Hz})$ 


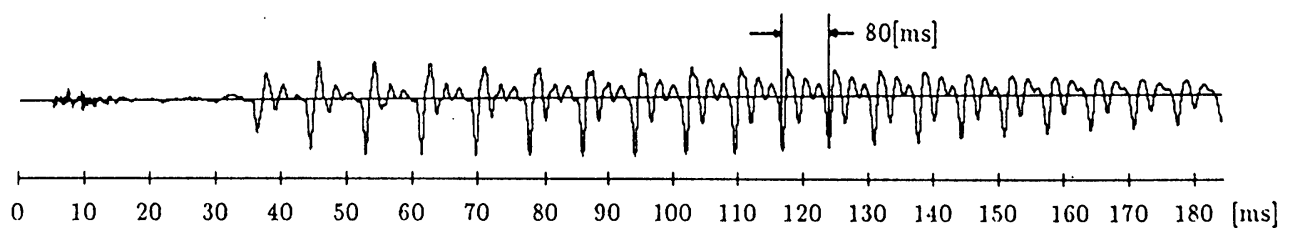

(a)
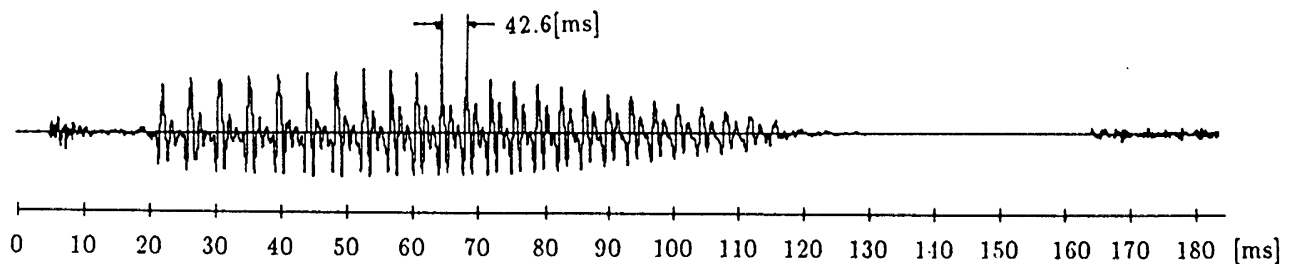

(b)

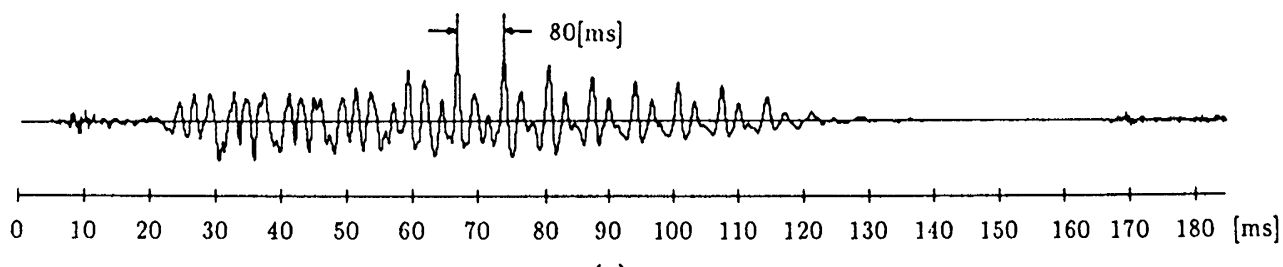

(c)

Fig.4 Three speech signals (a) is the recorded speech signal. (b) is affected by playbacking quickly $(\alpha=1.875)$. (b) is put into the system.

(c) is the output of the system. The pitches are corrected to $80 \mathrm{~ms}$.

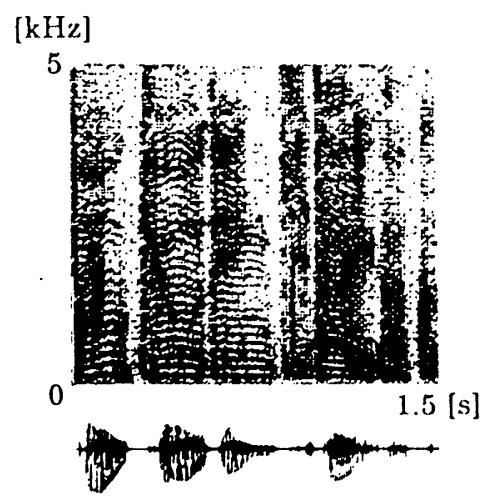

(a) $\alpha=1$

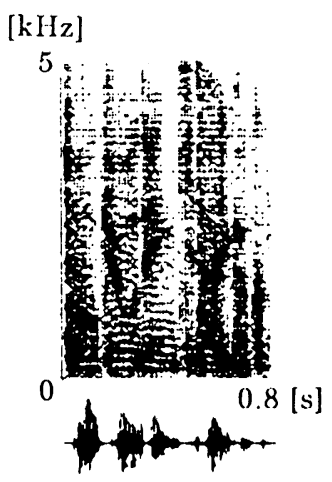

(b) $\alpha=1.875$

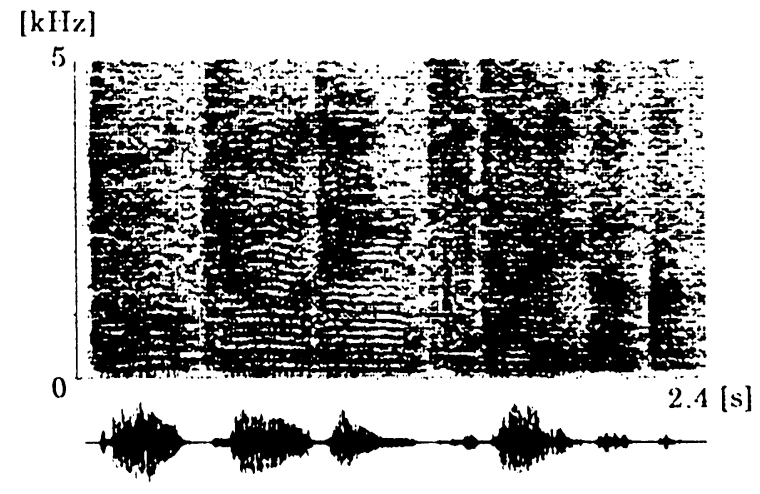

(c) $x=0.625$

Fig.5 Corrected speech signals and the spectrogram of a Japanese pronunciation, "To-kyo denki dai-gaku", playbacked at (a) normal speed $(\alpha=1)$, (b) fast speed $(\alpha=1.875)$ and (c) slow speed $(\alpha=0.625)$ 
れた音質であった．子音部においては各音韻の区別は十分 可能である．しかし高速再生時には若干明瞭度が下がる. この原因として，(a) 高速再生時には子音長も短くなるた め必然的に明嘹度が落ちること，(b) 本処理で設定した圧 伸処理带域が約 $5 \mathrm{kHz}$ 以下であること，(c) および子音に ついても母音と同様の圧伸処理をあてはめたために子音の スペクトル包絡を完全には再現できなかった可能性があ る，の三つが原因の候補として考えられる.

(a)の原因は避けることができない（b)について調べる ため, 圧伸処理の対象帯域を $6.5 \mathrm{kHz}$ まで搪張して圧伸処 理をおこない，試聴した．この結果，破裂音や破擦音の明 瞭度が上がることが確認できた. (c)について調べるため, 全子音を対象として圧伸処理後のスペクトログラムを視察 した. 子音のスペクトル包絡はきれいに復元されていた. このことと，圧伸処理帯域を広げることで明膫度が上がる ことから(c)は明瞭度を下げる原因ではないと考えられる。

以上のように，本論文で対象とした周波数帯域約 $5 \mathrm{kHz}$ 以下については, 期待した音質修正が可能であることが確
かめられた．子音の明膫度を上げるためには対象帯域を広 げればよい.つまりチャネル数を単に増加させればよく， ただちに可能である.

\section{3 シミュレーション 2}

中国語の会話音声を压伸処理したときの音質を評価す る. 対象音声は,「プリンストン大学は文学部だけの大学 ですか. いいえ, 総合大学です.」という意味の中国語の 会話である. 中国語を選んだ理由は，中国語特有の抑揚の 急な変化, 寸なわちピッチの急変するような音声に対応で きるかを調べるためである．圧伸係数 $\alpha$ を0.65および1. 6 として再生された音声に対し, 圧伸処理後のスペクトログ ラムをFig. 6に示寸. フォルマント位置, 基本周波数が修 正されているのがわかる.ネイティブの中国人に試聴して もらい, 压伸処理後の音声は個人性がよく保存されてお り，音質も良いとの評価を得た．このことから本圧伸処理 は，ピッチの急変するような音声にも十分対応できると考 えられる。

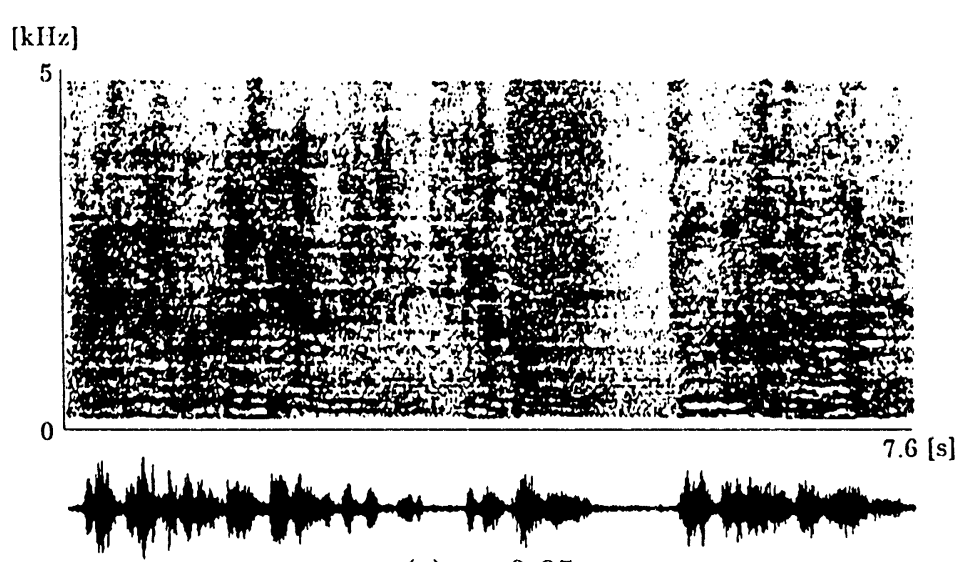

(a) $\alpha=0.65$

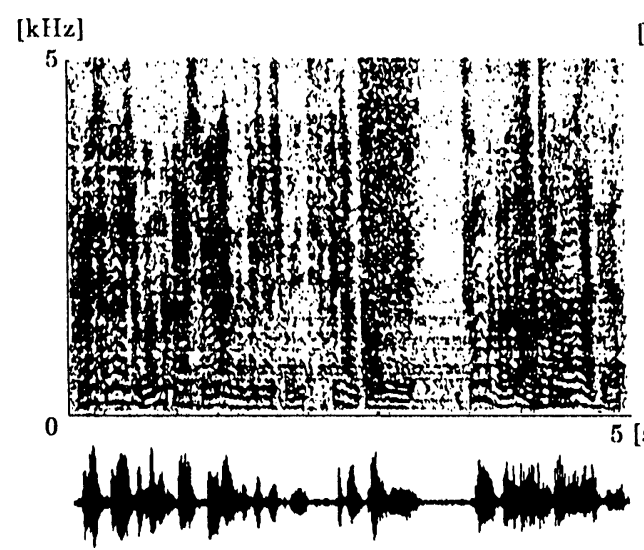

(b) $\alpha=1$

[kIIz]

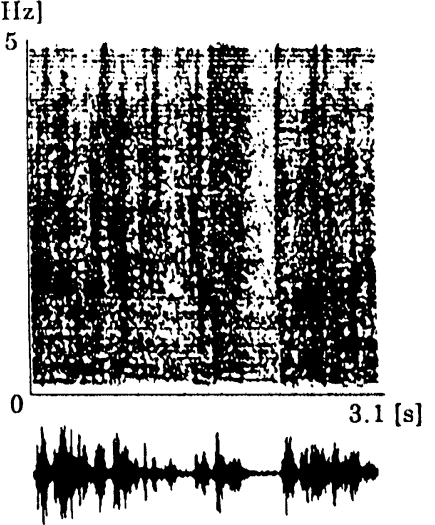

(c) $\alpha=1.6$

Fig.6 Corrected speech signals and spectrogram of a Chinese sentence at (a) slow speed $(\alpha=0.65)$, (b) normal speed and (c) fast speed $(\alpha=1.6)$ 


\section{4. 考察}

圧伸処理を波形処理により実現する方法では，処理以前 の音声パラメータなどの情報はそこで途切れてしまう. 本 方式では単純な基本形だけの処理で圧伸処理をおこなって いるため, 情報は処理後も保存されている．新しく処理の 追加が必要になった場合，たとえば子音の微妙な時間長と か話の間などの調整処理をおこなう場合にも，必要な情報 は各チャネル内にて保存されているため，これを利用して おこなえばよい。

圧伸処理のチャネル数について述べる．BPF の通過帯 域幅は, 母音の基本周波数の高調波成分を 1 つだけ抽出す るために $80 \alpha[\mathrm{Hz}] に$ 設定した. しかし，高域にほぼ連続 に分布したスペクトルを持つ子音に対しては，必ずしも狭 带域である必要はないと考えられる．子音のスペクトル構 造を保存しつつ, 各 BPF の通過带域幅を広げれば，あま りチャネル総数を增やすこと無く音質の改善が図れる. 同 様に音質を落とさずに圧伸処理チャネル数を城らすことも 可能であると考えられる.このことはシステム規模を縮小 させる場合に有効である.

ハードウェアによる実現方法について述べる．ワークス テーション上では, 以上のシミュレーションの単チャネル ごとの実時間圧伸処理が可能であった. よってチャネルご とにDSP を用いればハードウェア単体による実時間圧伸 処理が可能である. ハードりェアシステムへの入力は, 再 生機からの録音音声ならでに圧伸係数值である，全体模成 が Fig.7 で示されるようなシステムとなる. ハードウェア は DSP を複数個使用した DSP システムとし，これに前述 のアルゴリズムを移植すればよい。

この DSP システムは, 各チャネルでの処理が完全並列 処理となるように構成される. まず考えられるのは各チャ ネルごとに 1 個ずつの DSP を割り当てる構成である.こ こで, 1 つの DSP で複数チャネルの処理が可能であれば その出力を複数チャネル分の加算結果となるように設計寸 ればよく, DSP の個数は逆数的に減らすことができる.

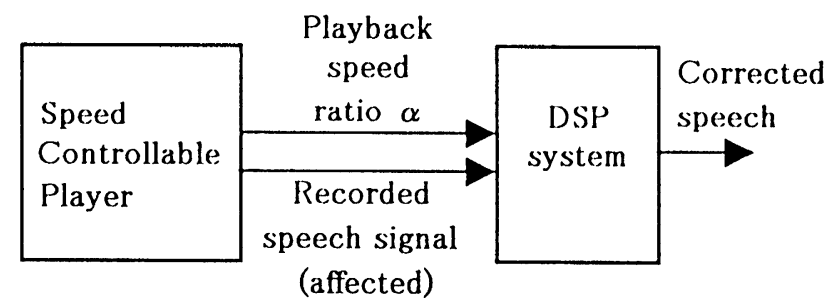

Fig.7 Hardware components of the system

\section{5. まとめ}

本論文では，再生速度比に応じた圧伸処理を周波数軸上 で実現する一方法について述べた．実時間処理可能なアル ゴリズムを作成し，そのプログラムをワークステーション 上に実現し，シミュレーションをおこなった．次の結果を 得 $大$.

（1）この圧伸処理アルゴリズムが，母音のような調波構造 のスペクトルを持つ音声に対してよく適合することが 確認できた.

（2）高い周波数に連続したスペクトル分布を持つ子音につ いても，圧伸処理後のスペクトル分布はよく復元され る. 処理後の音声を聞いても明膫度の著しい低下はな い.よって, この圧伸処理アルゴリズムは子音にも適 用できるといえる.

（3）抑揚が急な中国語にもよく対応する，すなわちピッチ の急変する場合にも対応できると考えられる.

以上のシミュレーションについて, ワークステーション 上における単チャネルの実時間圧伸処理を実現した. チャ ネルごとに DSP を用いればハードウェア単体による実時 間圧伸処理が可能である. 高速再生することで短時間闒き 取りに対して有効と考えられる. 特に, 低速再生すること で高龄者に対する聞き取り支援等に有効と考えられる. 謝辞

本研究に携わった本学情報通信工学科情報システム研究 室諸氏に感謝する.

\section{参考文献}

1) 中村 章,清山信正,池沢 龍,都木 徽.高品質リアルタイ ム話速変換システム.信学技報 1992;SP92(9):41-48.

2 ) Schroeder MR, Flanagan Л and Lundry EA. Band-width compression of speech by analyticsignal rooting. Proc.IEEE 1967;55(3):396-401.

3 ) 戸塚良則.解析信号法を用いた音声の継続時間の圧縮 伸張.NHK 技研 1971;23(6):461-471.

4 ）小坂雅博,横堀進義,藤田忠正.会話の時間軸を圧縮伸張 するテープレコーダ.日経エレクトロニクス 1976;76 (7):92-130.

5 ）河原英紀. 聴覚の情景分析が生み出した高品質 VOCODER:STRAIGHT. 日本音響学会誌 1998;54(7): 521-526.

6 ）都木徽.放送における話速変換:話者や音環境の多様性 への対応. 日本音響学会誌 1998;54(7):533-538.

7 ）宮坂栄一小特集に寄せて 感性の領域に迫る音処理技 術. 日本音響学会誌 1998;54(7):506-507.

8 ）志村隆史, 大西孝史, 小椋靖夫, 平松啓二. 解析信号 法を用いた音声の時間軸圧縮伸張処理の実現.電子情 報通信学会. 1993;秋季大会講演論文集:A-126 